University of Nebraska - Lincoln

DigitalCommons@University of Nebraska - Lincoln

$6-20-2019$

\title{
Influence of Environmental Stress and Anthropogenic Disturbance on the Energy Expenditure of Wintering Northern Pintails (Anas acuta)
}

\author{
Dustin P. Taylor \\ U.S. Fish and Wildlife Service, Klamath Basin NWR Complex, dustin_taylor@fws.gov \\ Daniel A. Dvorett \\ Oklahoma Conservation Commission \\ John N. Vradenburg \\ U.S. Fish and Wildlife Service, Klamath Basin NWR Complex \\ Loren M. Smith \\ Oklahoma State University
}

Follow this and additional works at: https://digitalcommons.unl.edu/usfwspubs

Taylor, Dustin P.; Dvorett, Daniel A.; Vradenburg, John N.; and Smith, Loren M., "Influence of Environmental Stress and Anthropogenic Disturbance on the Energy Expenditure of Wintering Northern Pintails (Anas acuta)" (2019). US Fish \& Wildlife Publications. 558.

https://digitalcommons.unl.edu/usfwspubs/558

This Article is brought to you for free and open access by the US Fish \& Wildlife Service at DigitalCommons@University of Nebraska - Lincoln. It has been accepted for inclusion in US Fish \& Wildlife Publications by an authorized administrator of DigitalCommons@University of Nebraska - Lincoln. 


\title{
Influence of Environmental Stress and Anthropogenic Disturbance on the Energy Expenditure of Wintering Northern Pintails (Anas acuta)
}

\author{
Dustin P. Taylor ${ }^{1, *}$, Daniel A. Dvorett ${ }^{2}$, John N. Vradenburg ${ }^{1}$ and Loren M. Smith ${ }^{3}$ \\ ${ }^{1}$ U.S. Fish and Wildlife Service, Klamath Basin NWR Complex, 4009 Hill Road, Tulelake, California, 96134, USA \\ ${ }^{2}$ Oklahoma Conservation Commission, 2800 North Lincoln Boulevard, Oklahoma City, Oklahoma, 73105, USA \\ ${ }^{3}$ Department of Integrative Biology, Oklahoma State University, 501 Life Sciences West, \\ Stillwater, Oklahoma, 74078, USA
}

*Corresponding author; E-mail: dustin_taylor@fws.gov

\begin{abstract}
Winter conditions impose hardships on waterfowl, impacting how they apportion energy and time. Human disturbances may affect this energetic balance, influence lipid reserves, and potentially survival. Objectives of this study were to determine effects of environmental and anthropogenic factors on energetic expenditure (kcal/day) of Northern Pintails (Anas acuta) in behaviors commonly associated with a disturbance response (alert, locomotion, and flight) during winter 2008-2009 and 2009-2010 at Bosque del Apache National Wildlife Refuge in central New Mexico, USA. The refuge is a frequently visited ecotourism destination with over 170,000 visitors each winter. Thermoregulatory cost, time-of-winter, amount of natural and anthropogenic disturbances, and forage availability were examined to determine their influence on pintail energetic response (e.g., flight, locomotion, alert behavior). Average number of pintails ranged from 7,524-15,769. Using Akaike Information Criteria, the top-ranked model indicated that increased thermoregulatory cost, and by association decreased temperature, may cause a decline in energetic response of pintails to disturbances. Modeled values for energetic response had a mean $( \pm \mathrm{SE})$ of $175 \pm 11.5 \mathrm{kcal} /$ day in year 1 , and $111.7 \pm 7.22$ $\mathrm{kcal} /$ day in year 2. Neither the amount of disturbance nor forage availability strongly influenced energetic response. Results of this study raise questions about the efficacy of using behavior or energy expenditure data, alone, to assess anthropogenic disturbance effects on waterfowl. Received 18 May 2018, revised 11 December 2018 , accepted 20 June 2019.
\end{abstract}

Key words.- disturbance, energetics, environmental stress, Northern Pintail, thermoregulation, wildlife refuge, waterfowl, winter.

Waterbirds 42(3): 294-303, 2019

Winter imposes restrictions on how wintering waterfowl apportion both their energy and time (Riddington et al. 1996). Further, human caused disturbances (such as hunting and ecotourism) can alter the behavior of wintering waterfowl, potentially impacting energy expenditure and survival (Fredrickson and Drobney 1979), and may impact distribution, pair-bonding, migration, and subsequent reproductive success (Riddington et al. 1996). For example, during winter in North America, Northern Pintails (Anas acuta; hereafter referred to as "pintails") might be most sensitive in January and early February as they carry low levels of lipid reserves and temperatures are the coldest (Smith and Sheeley 1993; Madsen and Fox 1995).

Time-activity budgets have been used to evaluate responses of wintering waterfowl to environmental factors (Miller 1985; Paulus 1988; Bergan and Smith 1989), anthropo- genic disturbance (Riddington et al. 1996), and life-cycle events (Miller 1985). There are several behavioral adjustments an individual might make in response to disturbance, including: 1) altered feeding rates; 2) altered diet and/or habitat selection; 3) increased night-time feeding; 4) decreased time spent in courtship, preening, and resting behaviors; 5) increased locomotion and alert behavior; and 6) increased time spent in flight (Madsen and Fox 1995; Riddington et al. 1996; Pease et al. 2005). Of these activities, flight is considered the most energetically expensive, with costs estimated at $12.5 \times$ basal metabolic rate (BMR) (Wooley and Owen 1978). In comparison, feeding and swimming/walking are only 1.8 and $2.3 \times$ BMR, respectively (Wooley and Owen 1978). Disturbances that redirect waterfowl into energetically costly behaviors might affect lipid reserves, and ultimately survival, particularly during periods of increased environmental stress. 
In most years, the Middle Rio Grande River Valley in New Mexico, USA represents the northern extent of wintering habitat for significant concentrations of pintails using the Intermountain West. Historically, wetland habitat was abundant in the Middle Rio Grande River Valley, however, land-use change and loss of wetland habitat have resulted in dense aggregations of waterfowl utilizing the sparse remaining habitat (Post et al. 1998). In addition, waterfowl wintering in the Middle Rio Grande Valley often experience temperatures $\leq 0{ }^{\circ} \mathrm{C}$ and temporal reductions in food availability due to ice formation on wetlands. Freezing temperatures have direct energetic consequences (Calder 1974; Baldassarre and Bolen 2006), and energetic costs may be exacerbated by reduced food availability due to freezing events or snow (Jorde et al. 1984; Browne and Dell 2007). Environmental conditions, such as freezing events, may directly affect the behavior responses and energetic expenditure of wintering waterfowl (e.g., Jorde $e t$ al. 1984). Our objectives were to determine the effects of environmental and anthropogenic factors on wintering pintails energetic expenditure. Information from this study is intended to assist wildlife conservation decision-makers by elucidating possible factors that affect pintail energetic expenditure within the northern areas of their wintering range.

\section{Methods}

\section{Study Area}

The study site was located at Bosque del Apache National Wildlife Refuge (NWR; $33^{\circ} 52^{\prime} 9^{\prime \prime} \mathrm{N}, 106^{\circ} 50^{\prime}$ $35^{\prime \prime} \mathrm{W}$ ), within the Middle Rio Grande Valley, $30 \mathrm{~km}$ south of Socorro, New Mexico, USA. Of several state and federally managed refuges within the Middle Rio Grande Valley, the Bosque del Apache NWR is the largest, with $>1,214$ ha of wetlands (Lee et al. 2007) that provide winter habitat for thousands of waterfowl. The refuge manages $>70$ wetland units, and the water level within each unit is flooded and drained to promote desired annual vegetation and to encourage waterfowl use (Taylor 2010). The most abundant dabbling ducks at the refuge in winter are pintails, Green-winged Teal (Anas carolinensis), and Mallards (Anas platyrhynchos). Average monthly temperatures and minimum temperatures (from 1981-2010; Western Regional Climate Cen- ter 2019) in November $\left(8.1{ }^{\circ} \mathrm{C}\right.$; minimum $\left.2.9^{\circ} \mathrm{C}\right)$, December $\left(3.2^{\circ} \mathrm{C}\right.$; minimum $\left.-6.8^{\circ} \mathrm{C}\right)$, and January $\left(3.4{ }^{\circ} \mathrm{C}\right.$; minimum $-6.7^{\circ} \mathrm{C}$ ) are typical of winter climate in the arid southwestern USA, with temperatures frequently dropping below freezing. The Bosque del Apache is also a popular ecotourism destination for hiking, birding, and nature photography, and attracts $>170,000$ annual visitors between November and February each year, increasing the possibility for disturbance to winter waterfowl.

\section{Study Design}

We used focal sampling to determine time-activity budgets of female pintails (Altman 1974). Female pintails were the focus of this study because they have the greatest influence on pintail population dynamics (Cox et al. 1998). Observations were made using a $20-50$ × 80 spotting scope from a parked vehicle. Randomly selected females were observed for $5 \mathrm{~min}$, and the amount of time spent in each activity was recorded. Each individual was randomly chosen by moving the scope in a zigzag pattern across the flock and selecting the individual closest to the center of the scope's field of view (Davis and Smith 1998). Behavioral activity categories included: feeding, swimming/walking, resting, preening, alert, courting, aggression, and flight (Paulus 1988). We defined disturbed and undisturbed areas as areas with or without ecotourism access, respectively. In disturbed areas, we made observations from the refuge tour loop road, thus imitating ecotourism disturbance. In undisturbed areas, we made observations from a distance $>$ $300 \mathrm{~m}$ from the surveyed individuals to minimize our impact on waterfowl behavior. Undisturbed areas had at least one other wetland unit separating it from a road with public access or were located $>300 \mathrm{~m}$ from a road with public access.

We conducted time-activity budgets and recorded disturbances 2 days each week from 1 November-20 January each winter 2008-2009 and 2009-2010. Each week, we randomly selected surveyed units from areas with and without ecotourism access. Each survey day was equally divided into 3, 3-hr time blocks: morning (07:00-10:00 hr), noon (10:30-13:30 hr), and afternoon (14:00-17:00 hr). During each single 3-hr time block, we conducted 3 sets of 30-min focal time-activity budgets, resulting in $\leq 18$ focal individuals per time block. Disturbance type sampling occurred at the same frequency and is considered an index of disturbance and amount throughout the season. We categorized disturbance as either: natural (e.g. coyotes [Canis latrans] or raptors), vehicular, or pedestrian, and all disturbances within 300 meters of the center of the flock were documented (distance determined using a laser rangefinder).

We multiplied the percent time spent in each behavior by the resting metabolic rate (resting metabolic rate $[\mathrm{kcal} /$ day $]=100.7 \times$ body mass $^{0.74}$; Miller and Eadie 2006) to estimate the daily energy need for each species of interest. We used body mass $(\mathrm{g})$ data collected at Bosque del Apache NWR from a concurrent study (Taylor 2010). We then used a behavioral activity specific multiple of the basal metabolic rate (Wooley and Owen 
1978; Thompson and Baldassarre 1990) to estimate energy expenditure for every 5-min focal observation (kcal/5 min). Activity specific multipliers of the resting metabolic rate were not available, and we assumed that the relationship between the multiplier and basal or resting metabolic rates was similar.

We obtained hourly temperature $\left({ }^{\circ} \mathrm{C}\right)$ measurements from a local weather station at the Bosque del Apache NWR (Station ID BDAN5; Meso West 2015). We calculated lower critical temperature (LCT), the temperature where the metabolic rate must increase in order to maintain body temperature (LCT $=40 \times$ temperature $-47.2 \times$ body mass ${ }^{-0.18}$; Kendeigh et al. 1977). We used mean temperatures for each weekly period from the Friday before the survey week to the Friday of the survey week, and we used body mass data from Taylor (2010) described in the previous paragraph. We then calculated a proxy for thermoregulatory cost (average temperature - LCT) within each week period (hereafter referred to as thermoregulatory cost).

To assess forage availability, we calculated the difference between energetic supply and energetic demand for each species of interest. If the calculation resulted in a negative value, it would be considered an energetic deficit, if positive it would be an energetic surplus. Our calculations always resulted in an energetic surplus. Energetic supply is a function of available foraging habitat and the biomass and nutritional quality of foods within these specific habitats. We calculated energetic supply by multiplying the percent composition of major dabbling duck species at Bosque del Apache NWR (Greenwinged Teal, pintails, and Mallards), total metabolizable energy $(\mathrm{kcal} / \mathrm{kg})$, seed production $(\mathrm{kg} / \mathrm{ha})$, and percent flood inundation. Percent composition was derived from weekly waterfowl surveys at the Bosque del Apache NWR and was used to account for competition for similar food resources (Heitmeyer 2010). We used a grid-based sampling technique to collect annual seed production estimates $(\mathrm{kg} / \mathrm{ha})$ and percent coverage for specific plant species from each actively managed wetland unit at the refuge. This sampling technique has been used at the refuge since 1992 (Laubhan and Fredrickson 1992). Seed production estimates were ranked as either poor, fair, or good production corresponding to site-specific production estimates (Laubhan and Fredrickson 1992). Percent coverage of plants, wetland size (ha), and seed production $(\mathrm{kg} / \mathrm{ha})$ values were used to calculate total seed production for each wetland unit in each year $(\mathrm{kg} / \mathrm{ha})$. Invertebrates are an important and essential resource for wintering waterfowl; however, site-specific invertebrate estimates were not available and therefore were not included in the energetic model. Therefore, our energetic supply estimates should be considered conservative. We used "matrix" estimates for herbaceous seeds to account for seasonal fluctuations (e.g. germination, deterioration, and consumption) in the availability/production of food resources in November, December, and January $(70 \%$, $60 \%$, and $50 \%$, respectively; Heitmeyer 2010). For each wetland unit, we estimated the percent of flood inundation as either $0 \%, 25 \%, 50 \%, 75 \%$, or $100 \%$ inunda- tion within each month of interest. Pintails are rarely observed field feeding in agricultural areas on or surrounding the refuge, therefore we assumed that all foraging resources were in managed wetland units.

We calculated energetic demand each year by multiplying the monthly average number of a specific waterfowl species, daily existence energy of a specific species, and days within each month. We used weekly waterfowl survey data from Bosque del Apache NWR. For each species we calculated their percentage of the total dabbling duck composition within a given month. We used the resting metabolic rate equation mentioned previously with body mass for Mallards $(1.17 \mathrm{~kg})$, Green-winged Teal $(0.31 \mathrm{~kg})$, and pintails $(0.94 \mathrm{~kg})$ (Heitmeyer 2010). Daily activities range from 1.4-12.5 times resting metabolic rate (Wooley and Owen 1978), depending on the specific behavior, and life history events such as thermoregulation and molt (Prince 1979). To account for these additional energetic requirements, we calculated Daily Existence Energy as $4 \times$ Resting Metabolic Rate (Heitmeyer 2010).

\section{Statistical Analyses}

We used an information theoretic approach (Burnham and Anderson 2002) to assess effects of thermoregulatory cost, year, daily amount of natural and anthropogenic disturbance, and energetic surplus on the energetic response to disturbance. A concurrent study found that hypothalamic-pituitary-adrenal axis sensitivity was $73 \%$ higher in the January of $2009 / 10$, and temperatures were on average $2.3^{\circ}$ and $2.6{ }^{\circ} \mathrm{C}$ colder (Taylor et al. 2014). Further dabbling ducks are predicted to migrate when cumulative Weather Severity Index values are $\geq-4.6$ (Schummer et al. 2010), and during our study, there were $3 \times$ the amount of days above the index threshold in year 2 compared to year 1 (Schummer $e t$ al. 2017). Therefore, year was included as a variable because both the physiological state of the pintails and the environmental conditions were different between years. We refer to the total energetic expenditure ( $\mathrm{kcal} /$ day) spent in behaviors commonly associated with a behavioral response to disturbance (alert, locomotion, and flight) as energetic response. Energetic expenditure was modeled with zero-inflated negative binomial models due to over dispersion and a high proportion of zeros using maximum likelihood estimation (Zuur et al. 2009). Over-dispersion was measured in Program R ( R Core Team 2013) using the regression-based test for mean variance equality (Cameron and Trivedi 1990). Zero-inflated negative binomial models included a negative binomial component to model energy expenditure in behaviors commonly associated with disturbance and a binomial component to model the probability of the absence of disturbance response behavior (expressed in kcal). Models were ranked using Akaike's Information Criteria for small sample sizes $\left(\mathrm{AIC}_{\mathrm{C}}\right.$ ). Candidate models were selected a priori, and models and $\mathrm{AIC}_{\mathrm{C}}$ scores $<2$ were considered the set of potential best models. All AIC analyses were performed in Program R (R Core Team 2013). Candidate models, including interactions, were selected a priori, and models and 
$\mathrm{AIC}_{\mathrm{C}}$ scores $<2$ were considered the set of potential best models. All AIC analyses were performed in Program R (R Core Team 2013). We used the Colldiag function in $\mathrm{R}$ to assess collinearity among independent variables (R Core Team 2013). Week was initially selected as a potential variable for inclusion in AIC models but was removed due to moderate collinearity with thermoregulatory cost (condition index of 33).

\section{RESUlTS}

In winters 2008-2009 and 2009-2010, mean weekly temperatures ranged from - 0.9 to $10.6{ }^{\circ} \mathrm{C}$, with temperatures generally colder in winter 2009-2010 (Table 1). Amount of flooded wetland habitat in winters ranged from 272-681 ha, with the lowest area in November each winter and highest area in January each winter (Table 2). We calculated mean $( \pm \mathrm{SE})$ seed production at $2,221.1 \pm 257.2$ and $1,497.8 \pm 182.7 \mathrm{~kg} / \mathrm{ha}$ in winters 2008-2009 and 2009-2010, respectively. Waterfowl surveys were dominated by pintails, Green-winged Teal, and Mallards, with these three species representing $>99 \%$ of the total dabbling duck population. Average number of winter waterfowl (all three species) ranged from 21,107-40,574; and average number of pintails ranged from 7,52415,769 (Table 2). Mean monthly body mass of female pintails ranged from $0.77-0.99 \mathrm{~kg}$ (Taylor 2010), with lowest masses observed in January each year (Table 2).

Table 1. Mean (SE) weekly temperatures (from the Friday before the survey week to the Friday of the survey week) at Bosque del Apache National Wildlife Refuge, New Mexico, USA from 1 November-20 January each winter 2008-2009 and 2009-2010.

\begin{tabular}{lcc}
\hline \hline Survey Week & $\begin{array}{c}\text { Winter } \\
\text { 2008-2009 } \\
\text { Temperatures }\left({ }^{\circ} \mathrm{C}\right)\end{array}$ & $\begin{array}{c}\text { Winter } \\
\text { 2009-2010 } \\
\text { Temperatures }\left({ }^{\circ} \mathrm{C}\right)\end{array}$ \\
\hline 1 & $10.6(0.8)$ & $5.3(0.8)$ \\
2 & $6.8(0.7)$ & $9.7(0.8)$ \\
3 & $3.8(0.8)$ & $3.6(1.4)$ \\
4 & $4.9(0.6)$ & $2.5(0.8)$ \\
5 & $7.7(0.7)$ & $1.5(0.5)$ \\
6 & $3.0(0.7)$ & $2.3(0.6)$ \\
7 & $6.0(0.2)$ & $2.0(0.6)$ \\
8 & $4.8(0.6)$ & $2.6(0.9)$ \\
9 & $0.4(0.6)$ & $-0.9(0.5)$ \\
10 & $3.9(0.6)$ & $-0.2(0.6)$ \\
11 & $1.7(0.6)$ & $-0.4(0.7)$ \\
\hline
\end{tabular}

We conducted 391 and 749, 5-min, timeactivity budgets for individual female pintails in years 1 and 2, respectively (Fig. 1). The top-ranked model indicated that energetic response was correlated with an interaction between year and thermoregulatory cost (Table 3). Both binomial and negative binomial portions of the model showed similar results, but for clarity only the results from the negative binomial model are presented. In year 1, energy-use associated with an energetic response to disturbance increased with thermoregulatory cost. The equation derived from the model in year 1 was: 5.15 - $(0.0495 \times$ thermoregulatory cost $)$. Whereas in year 2 , the energy use associated with an energetic response to disturbance decreased as thermoregulatory cost increased: $4.787+$ $(0.0226 \times$ thermoregulatory cost $)$. In summary, in year 1 birds spent more energy, and in year 2 birds spent less energy, during periods when thermoregulatory cost was the lowest. In a concurrent study, we found that in winter 2009-2010, female pintails demonstrated a decreased ability to respond to disturbances, including reduced flight, locomotion, and alert behavior (Taylor 2010). For thermoregulatory cost, values included in the model had a mean of $-8.42 \pm 1.8 \mathrm{SE}$ in year 1 and $-10.91 \pm 0.3$ in year 2 . Modeled values for the energetic response had a mean of $175 \pm 11.5 \mathrm{SE} \mathrm{kcal} /$ day in year 1 , and $111.7 \pm 7.22 \mathrm{kcal} /$ day in year 2 . We did not find support for models that included natural or anthropogenic disturbance, nor energetic surplus. Collinearity was found to be minimal, and the greatest value was 23 (below the commonly used threshold of 30 ).

\section{Discussion}

In our study, thermoregulatory cost had the greatest effect on energetic response of pintails. Energetic response to disturbance also decreased as thermoregulatory cost increased in the colder winter. In addition, the cumulative impact of multiple colder days may influence the energetic response of pintails to disturbance, and that energetic response varies among years. Further, our findings highlight limitations to the application 
Table 2. Wetland size, waterfowl numbers, and mass (from Taylor 2010) of female Northern Pintails (Anas acuta) at Bosque del Apache National Wildlife Refuge, New Mexico, USA in winters 2008-2009, 2009-2010. Waterfowl include Mallards (Anas platyrhynchos), Green-winged Teal (Anas carolinensis), and Northern Pintails. Mass only recorded once in each January.

\begin{tabular}{|c|c|c|c|c|c|}
\hline \multirow[b]{2}{*}{ Month/Year } & \multirow{2}{*}{$\begin{array}{l}\text { Wetland } \\
\text { Size (ha) }\end{array}$} & \multirow{2}{*}{$\begin{array}{c}\text { Average No. } \\
\text { Waterfowl }\end{array}$} & \multirow{2}{*}{$\begin{array}{l}\text { Average No. } \\
\text { Pintails }\end{array}$} & \multicolumn{2}{|c|}{$\begin{array}{c}\text { Mean (SE) } \\
\text { Body Mass (kg) of Female Pintails }\end{array}$} \\
\hline & & & & $1^{\text {st }}$ Half of Month & $2^{\text {nd }}$ Half of Month \\
\hline November 2008 & 272 & 21,107 & 7,524 & $0.93(0.03)$ & $0.99(0.03)$ \\
\hline December 2008 & 523 & 33,666 & 11,289 & $0.94(0.01)$ & $0.89(0.02)$ \\
\hline January 2009 & 665 & 30,549 & 13,545 & $0.77(0.01)$ & - \\
\hline November 2009 & 324 & 24,053 & 8,343 & $0.91(0.02)$ & $0.92(0.02)$ \\
\hline December 2009 & 509 & 40,574 & 15,511 & $0.97(0.02)$ & $0.88(0.02)$ \\
\hline January 2010 & 681 & 36,505 & 15,769 & $0.78(0.01)$ & - \\
\hline
\end{tabular}

of behavior or energy expenditure data to assess anthropogenic disturbance effects to waterfowl, as environmental conditions and a bird's physiological state might be a better predictor of energetic expenditure than the amount of disturbance.

Environmental conditions can directly (e.g., Jorde et al. 1984) and indirectly (e.g., Hepp et al. 1986) affect behavioral responses of wintering waterfowl. Pintails experienced comparatively greater environmental hardship in the second winter and the cumulative effects of these hardships may have reduced the likelihood of energetically expensive avoidance behaviors. Prior to arrival in the second winter, pintails breeding in southern Alberta (considered to be the most critical breeding areas for pintails utilizing the Middle Rio Grande Valley; Bellrose 1980; Johnson and Grier 1988) experienced drought conditions, resulting in breeding estimates that were $28 \%$ lower than the previous year (USFWS 2009). In that year, pintails arrived at Bosque del Apache NWR later (there were $68 \%$ less pintails in October 2009 than in October 2008), and had 23\% lower lipid reserves in early November than in the year before (Taylor 2010). As the season progressed, temperatures were on average $2.3^{\circ}$ and $2.6{ }^{\circ} \mathrm{C}$ colder, in December and January compared to $2008 / 09$, respectively, coinciding with seasonally low lipid reserves (Taylor 2010). Our results suggest that pintails reduce energy expenditures in relation to colder temperatures. This relationship has also been demonstrated in Canada Geese (Branta canadensis; Raveling et al. 1972), Black Ducks (Anas rubripes; Albright et al. 1983), and Atlantic Brant (Branta vernicle hro$t a$; Heise 2012). Severe winter weather may reduce food availability and may encourage migration to areas with comparatively favorable conditions (Bellrose and Sieh 1960; Beason 1978; Robb et al. 2001). Although our study indicates that pintails increase foraging and energy conservation behavior to cope with severe winter weather, if energetic needs are not met, pintails may migrate south during a period of seasonally low lipid reserves. Managers may reduce the energetic effects of severe environmental conditions by increasing the availability of high-quality foraging options (Jorde et al. 1984; Robb et al. 2001), and/or by providing sanctuary areas from anthropogenic disturbance.

Energetic responses to disturbance are likely dependent on an animal's physiological condition. Beale and Monaghan (2004) demonstrated that Turnstones (Arenaria interpres) in better body condition were more likely to respond to disturbances. For waterfowl, studies have found that birds with less body mass are more likely to be shot by hunters (e.g., Hepp et al. 1986; Heitmeyer et al. 1993), suggesting that a bird's condition affects their response(s) to potential threat(s). In addition, lipid reserves of wintering waterfowl naturally fluctuate and reach their seasonal low in mid-late winter (Thompson and Baldassarre 1990). The equation we 

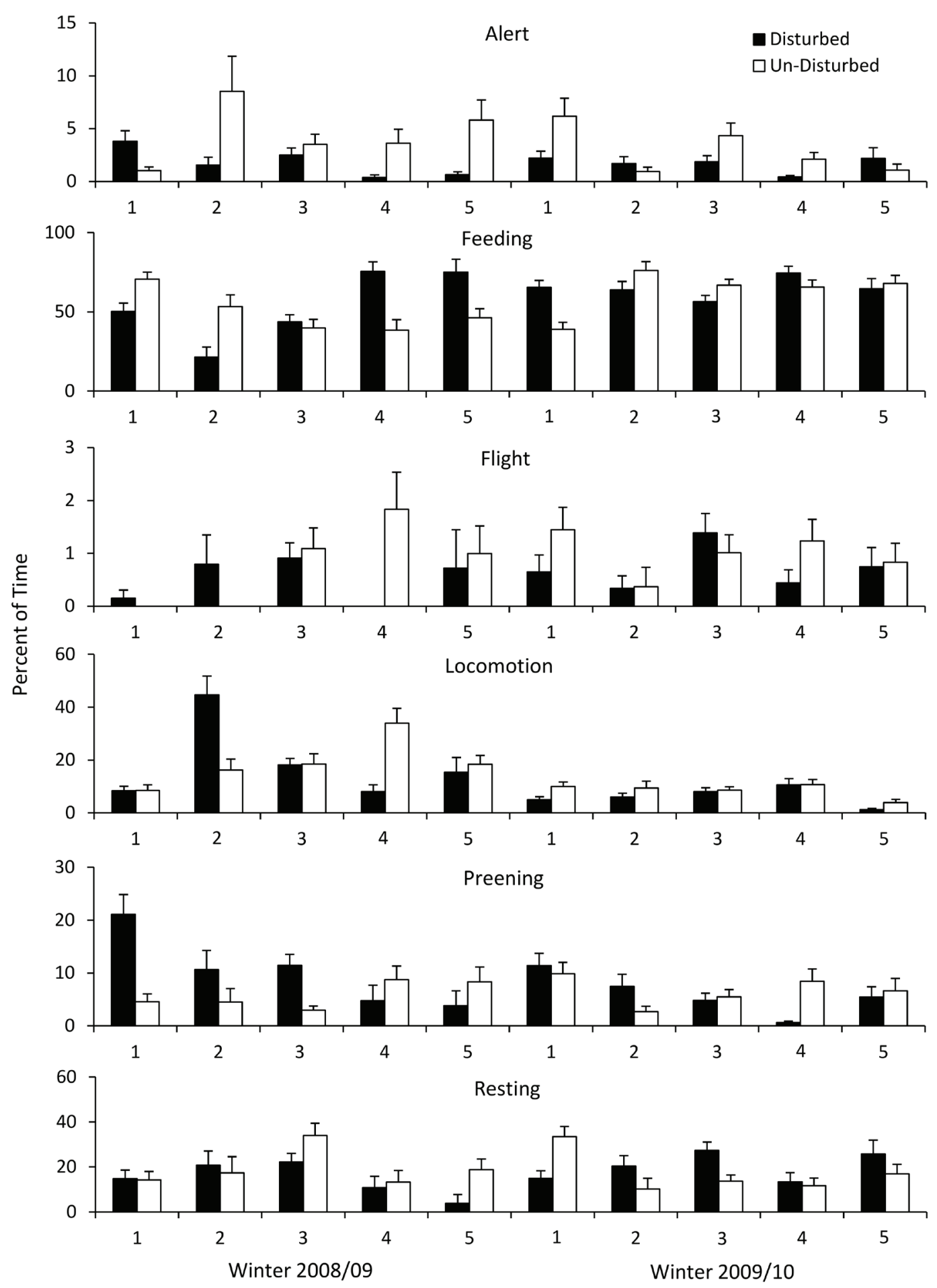

Figure 1. Diurnal time-activity budget of Northern Pintails (Anas acuta) during winter sampling periods in 2008, 2009, and 2010 at the Bosque del Apache National Wildlife Refuge, New Mexico, USA between wetland units with and without ecotourism disturbance. Period $1=1$ Nov -15 Nov; Period $2=16$ Nov -31 Nov; Period $3=1$ Dec -19 Dec; Period $4=20$ Dec -5 Jan; Period $5=6$ Jan -20 Jan. 


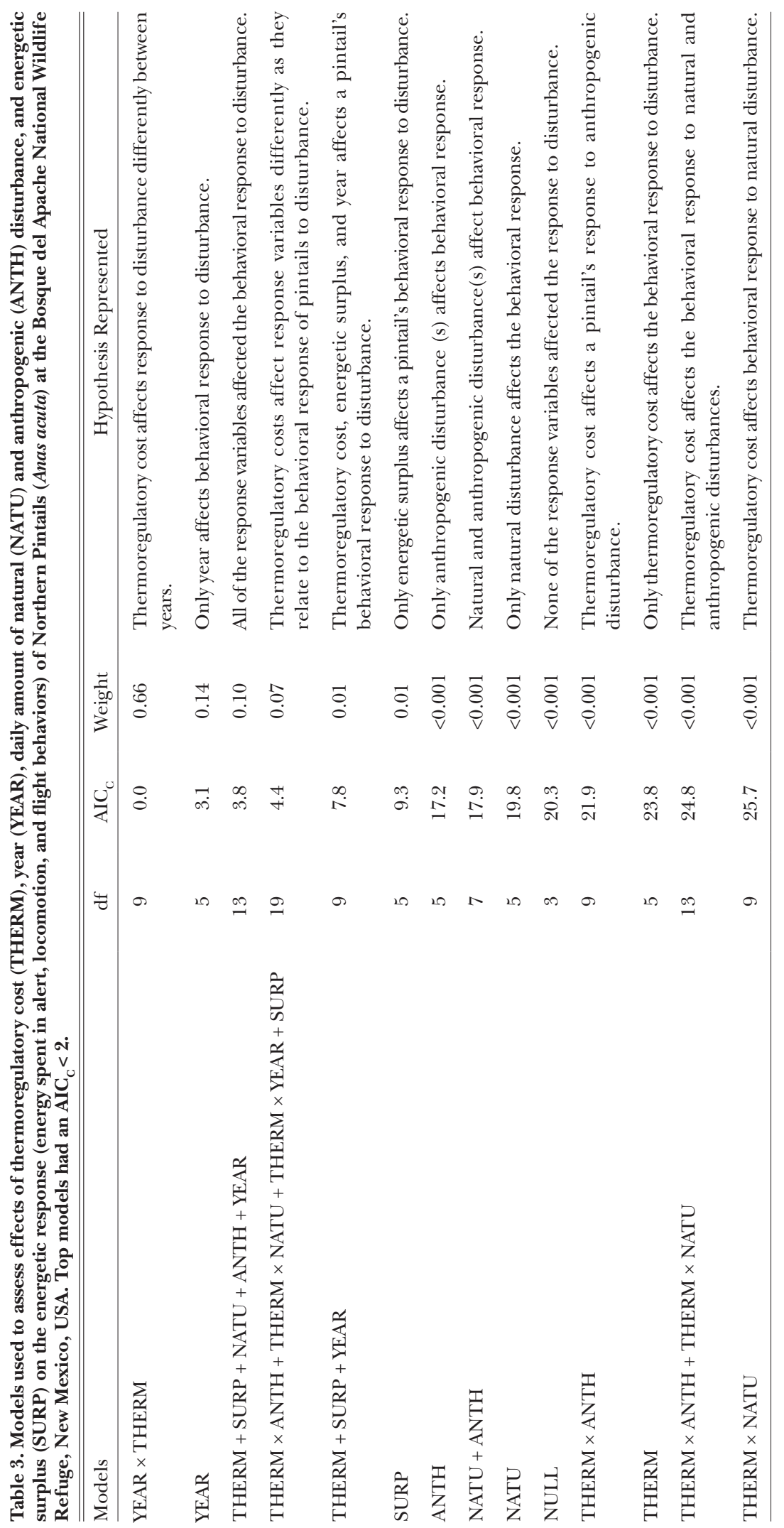


used to calculate thermoregulatory cost was influenced by temperature, body mass, and associated lipid reserves. Therefore, the negative correlation of energy expenditure with thermoregulatory cost in the colder winter can be attributed to seasonal low lipid reserves in mid-late winter coupled with comparatively colder temperatures.

Pintail hypothalamic-pituitary-adrenal axis sensitivity was $73 \%$ higher in the colder winter than during the warmer winter (Taylor $e t$ $a l$. 2014). Increased hypothalamic-pituitaryadrenal axis sensitivity may serve to redirect an individual into behaviors that best serve short-term survival fitness, particularly during periods of environmental hardships (Wingfield and Kitaysky 2002). Decreased quantity and quality of forage (Kitaysky $e t$ al. 1999; Fokidis et al. 2012) and temperature (Wingfield and Ramenofsky 1999) have been associated with increased hypothalamic-pituitary-adrenal axis sensitivity. A redirection of energy into behaviors that best support short-term survival is consistent with a reduced energetic response to disturbance in association with increased thermoregulatory costs.

Our findings raise questions about the efficacy of using behavior or energy expenditure data, alone, to assess anthropogenic disturbance effects. Ideally, interpretation of behavioral data would be coupled with information on physiological state (e.g., lipid reserves, molt stage, thermoregulatory costs, etc.) and environmental conditions. However, collection of this information is time intensive and difficult to interpret. Alternatively, daily ration models could be improved to provide insight into these relationships. For example, incorporation of energy costs associated with thermoregulation into daily existence energy estimates (McKinney and Williams 2005, Williams et al. 2014) or temporal food availability (Heitmeyer et al. 2010; Williams et al. 2014; Petrie et al. 2016) may improve energetic models. Incorporating the concept of temporal food availability could then be extended to freezing events. Inclusion of one or more of these factors into daily ration models could be used to better simulate how energetically costly behaviors (e.g. flight) associated with disturbance affect energetic demand relative to energetic availability. However, empirical studies would be needed to acquire these values. Recently, agent-based models have been proposed as an alternative to daily ration models (e.g. Williams et al. 2014). Among many possibilities, agent-based models may be able to incorporate cost of movement associated with disturbance events or could link body condition and survival metrics to environmental conditions (Williams et al. 2014).

\section{ACKNOWLEDGMENTS}

We thank Scott McMurry, Matthew Lovern, Colin Lee, Diana Iriate, Sara Blocker, and Nate Johnson for advice and technical assistance. In addition, we thank Tom Melanson, Bosque del Apache NWR manager who provided vehicles, employees, and refuge access. This project was supported by funding from Delta Waterfowl, the U.S. Fish and Wildlife Service (Region 2), and Oklahoma State University. We also thank the 2 anonymous reviewers whose suggestions helped to improve and clarify this manuscript. Trapping and handling was in compliance with the protocol outlined in the Oklahoma State University Animal Care and Use Permit Number AS099 and the Unites States Fish and Wildlife Service Special Permit Number 22520-2008Bio. All applicable ethical guidelines for the use of birds in research have been followed, including those presented in the Ornithological Council's "Guidelines to the use of Wild Birds in Research" (Fair et al. 2010). Disclaimer: The findings and conclusions in this article are those of the author(s) and do not necessarily represent the views of the U.S. Fish and Wildlife Service.

\section{Literature Cited}

Albright, J. J., R. B. Owen, Jr. and P. O. Corr. 1983. The effects of winter weather on the behavior and energy reserves of Blacks Ducks in Maine. Transactions of the Northeast Section of the Wildlife Society 40: 118-128.

Altman, J. 1974. Observational study of behavior: sampling methods. Behaviour 49: 227-267.

Baldassarre, G. A. and E. G. Bolen. 2006. Waterfowl ecology and management, 2nd ed. Krieger Publishing Co., Malabar, Florida.

Beale, C. M. and P. Monaghan. 2004. Behavioral responses to human disturbance: a matter of choice? Animal Behaviour 68: 1065-1069.

Beason, R. C. 1978. The influences of weather and topography on waterbird migration in the southwestern United States. Oecologia 32: 153-169.

Bellrose, F. C. 1980. Ducks, geese, and swans of North America, 2nd ed., Stackpole Books, Harrisburg, Pennyslvania. 
Bellrose, F. C., and J. G. Sieh. 1960. Massed waterfowl flights in the Mississippi flyway 1956 and 1957. Wilson Bulletin 72: 29-59.

Bergan, J. F. and L. M. Smith. 1989. Differential habitat use by diving ducks wintering in South Carolina. Journal of Wildlife Management 53: 11171126.

Browne, D. M. and R. Dell (Eds.). 2007. Conserving waterfowl and wetlands amid climate change. Ducks Unlimited, Memphis, Tennessee.

Burnham, K. P. and D. R. Anderson. 2002. Model selection and multimodel inference. Springer, New York, New York.

Calder, W. A. 1974. The consequences of body size for avian energetics. Pages 86-151 in Avian Energetics (R. A. Paynter, Ed.). Avian energetics. Nuttall Ornithological Club, Cambridge, Massachusetts.

Cameron, A. C. and P. K. Trivedi. 1990. Regressionbased tests for overdispersion in the Poisson model. Journal of Econometrics 46: 347-364.

Cox, R. R. Jr., A. D. Afton and R. M. Pace III. 1998. Survival of female Northern Pintails wintering in southwestern Louisiana. Journal of Wildlife Management 62: 1512-1521.

Davis, C. A. and L. M. Smith. 1998. Behavior of migrant shorebirds in playas of the southern high plains, Texas. Condor 100: 266-276.

Fair, J., E. Paul and J. Jones (Eds.). 2010. Guidelines to the use of wild birds in research. Ornithological Council, Washington, D.C.

Fokidis, H. B, des, Roziers, M. B., Sparr, R. A., Rogowski, C. P., Sweazea, K. L., and P. J. Deviche. 2012. Unpredictable food availability induces metabolic and hormonal changes independent of food intake in a sedentary songbird. Journal of Experimental Biology 215: 2920-2930.

Fredrickson, L. H. and R. Drobney. 1979. Habitat utilization by postbreeding waterfowl. Pages 119-129 in Waterfowl and wetlands-an integrated review (T.A. Bookhout Ed.). North Central Section of the Wildlife Society, Madison, Wisconsin.

Heise, J. R. 2012. Incorporating nocturnal activity of wintering Atlantic Brant (Branta bernicla hrota) into 24 hour time-activity and daily energy expenditure models. M.S. Thesis. University of Delaware, Newark, Deleware.

Hepp, G. R., R. J. Blohm, R. E. Reynolds, J. E. Hines and J. D. Nichols. 1986. Physiological condition of autumn-banded Mallards and its relationship to hunting vulnerability. Journal of Wildlife Management 50: 177-183.

Heitmeyer, M.E. 2010. A manual for calculating duckuse-days to determine habitat resource values and waterfowl population energetic requirements in the Mississippi Alluvial valley. Greenbrier Wetland Services Report 10-01. Blue Heron Conservation Design and Printing LLC Bloomfield, Missouri.

Heitmeyer, M. E., L. H. Fredrickson and D. D. Humburg. 1993. Evidence of Biases Associated with Hunter-Killed Mallards. Journal of Wildlife Management 57: 733-740.
Johnson, D. H. and J. W. Grier. 1998. Determinants of breeding distributions of ducks. Wildlife Monographs 100: 1-37.

Jorde, D. G., G. L. Krapu, R. D. Crawford and M. A. Hay. 1984. Effects of Weather on Habitat Selection and Behavior of Mallards Wintering in Nebraska. Condor 86: 258-265.

Kendeigh, S. C., V. R. Dol'nik and V. M. Gavrilov. 1977. Avian energetics. Pages 127-204 in Granivorous Birds in Ecosystems: Their Evolution, Populations, Energetics, Adaptations, Impact, and Control (J. Pinowski and S. C. Kendeigh, Eds.). Cambridge University Press, New York, New York.

Kitaysky, A. S., Piatt, J. F., Wingfield, J. C. and M. Romano. 1999. The adrenocortical stress-response of Black-legged Kittiwake chicks in relation to dietary restrictions. Journal of Comparative Physiology 169: 303-310.

Laubhan, M. K. and L. H. Fredrickson. 1992. Estimating seed production of common plants in seasonally flooded wetlands. Journal of Wildlife Management 56: 329-337.

Lee, C. K., J. P. Taylor, D. A. Haukos and M. C. Anderson. 2007. Winter survival of Northern Pintails in the Middle Rio Grande Valley, New Mexico. Western North American Naturalist 67: 79-85.

Madsen, J. and A. D. Fox. 1995. Impacts of disturbance on migratory waterfowl. Ibis 137: 67-74.

McKinney, R. A. and S. R. Williams. 2005. A new model to estimate daily energy expenditure for wintering waterfowl. The Wilson Bulletin 117: 44-55.

Meso West. 2015. Hourly temperature data from Bosque del Apache NWR weather station (BDAN5), retrieved from https://mesowest.utah.edu, accessed 15 March 2015.

Miller, M. R. 1985. Time budgets of northern Pintails wintering in the Sacramento Valley, California. Wildfowl 36: 53-64.

Miller, M.R. and J.M. Eadie. 2006. The allometric relationship between resting metabolic rate and body mass in wild waterfowl (Anatidae) and an application for estimation of winter habitat requirements. Condor 108: 166-177.

Paulus, S. L. 1988. Time-activity budgets of mottled ducks in Louisiana in winter. Journal of Wildlife Management 52: 711-718.

Pease, L. M., R. K. Rose and M. J. Butler. 2005. Effects of human disturbances on the behavior of wintering ducks. Wildlife Society Bulletin 33: 103-112.

Post D. M., J. P. Taylor, J. F. Kitchell, M. H. Olson, D. E. Schindler and B. R. Herwig. 1998. The role of migratory waterfowl as nutrient vectors in a managed wetland. Conservation Biology 12: 910-920.

Petrie, M. J., J. P. Fleskes, M. A. Wolder, C. R. Isola, G. S. Yarris and D. A. Skalos. 2016. Potential effects of drought on carrying capacity for wintering waterfowl in the Central Valley of California. Journal of Fish and Wildlife Management 7: 1-15.

Prince, H. H. 1979. Bioenergetics of postbreeding dabbling ducks. Pages 103-117 in Waterfowl and Wetlands: an Integrated Review. T. A. Bookhout (Ed.). 
Proceedings of the 1977 Symposium of the North Central Section of the Wildlife Society, Madison, Wisconsin.

Raveling, D. G., W. E. Crews, and W. D. Klimstra. 1972. Activity patterns of Canada geese during winter. The Wilson Bulletin 84: 278-295.

R Development Core Team. 2013. R: a language and environment for statistical computing, v. 2.14.3. R Foundation for Statistical Computing,Vienna, Austria. http://www.R-project.org/, Accessed 17 November 2012.

Riddington, R., M. Hassall, S. J. Lane, P. A. Turner and R. Walters. 1996. The impacts of disturbance on the behavior and energy budgets of Brent Geese (Branta b. bernicula). Bird Study 43: 269-279.

Robb, J. R., G. M. Tori, and R. W. Kroll. 2001. Condition indices of live-trapped American Black Ducks and Mallards. Journal of Wildlife Management 65: 755-764.

Schummer, M. L., R. M. Kaminski, A. H. Raedeke, and D. A. Graber. 2010. Weather-related indices of autumn-winter dabbling. Journal of Wildlife Management 74: 94-101.

Schummer M. L., J. M. Coluccy, M. Mitchell, and L. Van Den Elsen. 2017. Long-term trends in weather severity indices for dabbling ducks in eastern North America. Wildlife Society Bulletin 41: 1-5.

Smith, L. M. and D. G. Sheeley. 1993. Factors affecting condition of Northern Pintails wintering in the Southern High Plains. Journal of Wildlife Management 57: 62-71.

Taylor, D. P. 2010. The effects of tourism disturbance on the body condition, behavior, and corticosterone levels of wintering Northern Pintails. M.S. Thesis, Oklahoma State University, Stillwater, Oklahoma.

Taylor, D. P., J. N. Vradenburg, L. M. Smith, M. B. Lovern and S. T. McMurry. 2014. Effects of anthropogenic disturbance and environmental stress on the corticosterone levels of wintering Northern Pintails (Anas acuta). Canadian Journal of Zoology 92: 185193.

Thompson, J. D. and G. A. Baldassarre. 1990. Carcass composition of nonbreeding Blue-winged Teal and Northern Pintails in Yucatan, Mexico. Condor 92: 1057-1065.

U.S. Fish and Wildlife Service. 2009. Waterfowl population status, 2009. Unpublished report, U.S. Department of the Interior, Fish and Wildlife Service, Migratory Bird Office, Washington, D.C.

Western Regional Climate Center. 2019. Bosque del Apache, New Mexico monthly average and minimum temperatures. Reno, Nevada. http://www. wrcc.dri.edu/cgibin/cliMAIN.pl?nm1138, accessed 28 June 2019.

Williams, C. K., B. D. Dugger, M. G. Brasher, J. M. Coluccy, D. M. Cramer, J. M. Eadie, M. J. Gray, H. M. Hagy, M. Livolsi, S. R. McWilliams, G. J. Soulliere, J. M. Tirpak and E. B. Webb. 2014. Estimating habitat carrying capacity for migrating and wintering waterfowl: considerations, pitfalls, and improvements. Wildfowl Special Issue 4: 407-435.

Wingfield, J. C. and M. Ramenofsky. 1999. Hormones and the behavioral ecology of stress. Pages 1-51 in Stress Physiology in Animals (P. H. M. Balm, Ed.). Sheffield Academic Press Inc., Sheffield, U.K.

Wingfield, J. C. and Kitaysky, A. S. 2002. Endocrine responses to unpredictable environmental events: stress or anti-stress hormones? Integrative and Comparative Biology 42: 600-609.

Wooley, J. B., Jr. and R. B. Owen, Jr. 1978. Energy costs of activity and daily energy expenditure in the black duck. Journal of Wildlife Management 42: 739-745.

Zuur A. F., E. L. Ieno, N. J. Walker, A. A. Saveliev and G. M. Smith. 2009. Mixed effects models and extensions in ecology with R. Springer, New York, New York. 